\title{
Successful treatment of a malignant gastrinoma with streptozotocin
}

\author{
J. R. HAYES, N. O'CONNELL, T. O'NEILL, J. J. FENNELLY, AND \\ D. G. WEIR ${ }^{1}$
}

From the Sir Patrick Duns Hospital, Dublin, and The Departments of Medicine, Trinity College, Dublin and Queen's University, Belfast

SUMMARY The treatment with streptozotocin of a patient with metastatic gastrinoma is described. Two courses of intravenous streptozotocin were without effect. However, three months after two doses of $4 \mathrm{~g}$ streptozotocin were given into the coeliac axis, there was a marked reduction in hepatic size and a fall in fasting plasma gastrin levels from $1430 \mathrm{pmol} / 1$ to $240 \mathrm{pmol} / \mathrm{l}$. Seven months after treatment fasting plasma gastrin levels were $125 \mathrm{pmol} / \mathrm{l}$.

Total gastrectomy is the preferred surgical treatment for the Zollinger Ellison syndrome. By removing the gastrin target organ, the complications of excessive acid secretion are avoided with excellent immediate results (Ellison and Wilson, 1967). However, in less than $20 \%$ of cases is it possible to remove the pancreatic islet cell tumours (Isenberg et al., 1973). These are frequently multiple and at least two-thirds undergo metastatic spread. Thus patients may survive only to succumb to the effects of malignant disease and this complication is now responsible for over half the late deaths in this condition (Walsh and Grossman, 1975). In this report we describe a dramatic response to treatment with streptozotocin in a patient with metastatic gastrinoma.

\section{Case history}

A 36 year old woman presented in May 1970 with a 10 year history of epigastric pain. A barium meal showed large gastric and duodenal ulcers. In the following six months she required two separate operations for the repair of perforated duodenal ulcers and was referred for further investigation. In September 1970 she was admitted to Sir Patrick Duns Hospital, Dublin. Basal acid output (BAO) was $21 \mathrm{mEq} / \mathrm{h}$ and pentagastrin stimulated acid output (MAO) was $39 \mathrm{mEq} / \mathrm{h} ; 12$ hour nocturnal acid secretion was $2700 \mathrm{ml}$, and contained $270 \mathrm{mEq}$

1'Address for reprint requests: Donald Weir, Department of Medicine, Trinity College, Dublin.

Received for publication 12 January 1976
$\mathrm{HCl}$. Multiple jejunal ulceration was seen on another barium meal examination. On the basis of these investigations a presumptive diagnosis of the Zollinger Ellison syndrome was made and at laparotomy in March 1971 a pancreatic tumour was found; two tumours were also noted in the liver. A partial pancreatectomy with resection of the liver tumours was performed. The tumours had the histological appearance of pancreatic islet cell carcinoma. In May 1971 a total gastrectomy was performed after which the patient was free of epigastric pain. She did, however, complain of abdominal swelling. Marked hepatic enlargement was noted with the liver extending $20 \mathrm{~cm}$ below the right costal margin. In March 1972 alkaline phosphatase was 5 umol $S^{-1} / 1$, the serum-glutamic-oxaloacetic-transaminase (SGOT) was 0.99 umol $\mathrm{S}^{-1} / 1$, the serum-glutamicpyruvate-transaminase (SGPT) was $0.35 \mathrm{umol}^{-1}$ and a liver scan showed multiple filling defects. Serum bilirubin, calcium, phosphorus, urea, and electrolytes were within normal limits. The fasting blood sugar was $5 \mathrm{mmol} / \mathrm{l}$.

\section{Methods}

STREPTOZOTOCIN TREATMENT

Streptozotocin therapy was begun in April 1972 (Figure). Two doses of $0.8 \mathrm{~g}$ and then two further doses of $1.6 \mathrm{~g}$ were given intravenously with an interval between each dose of seven days. In June the patient was given another course of intravenous treatment. Four doses of $\mathbf{2} \mathrm{g}$ streptozotocin were given with a seven day interval between each dose. In August, $4 \mathrm{~g}$ streptozotocin was given through a 


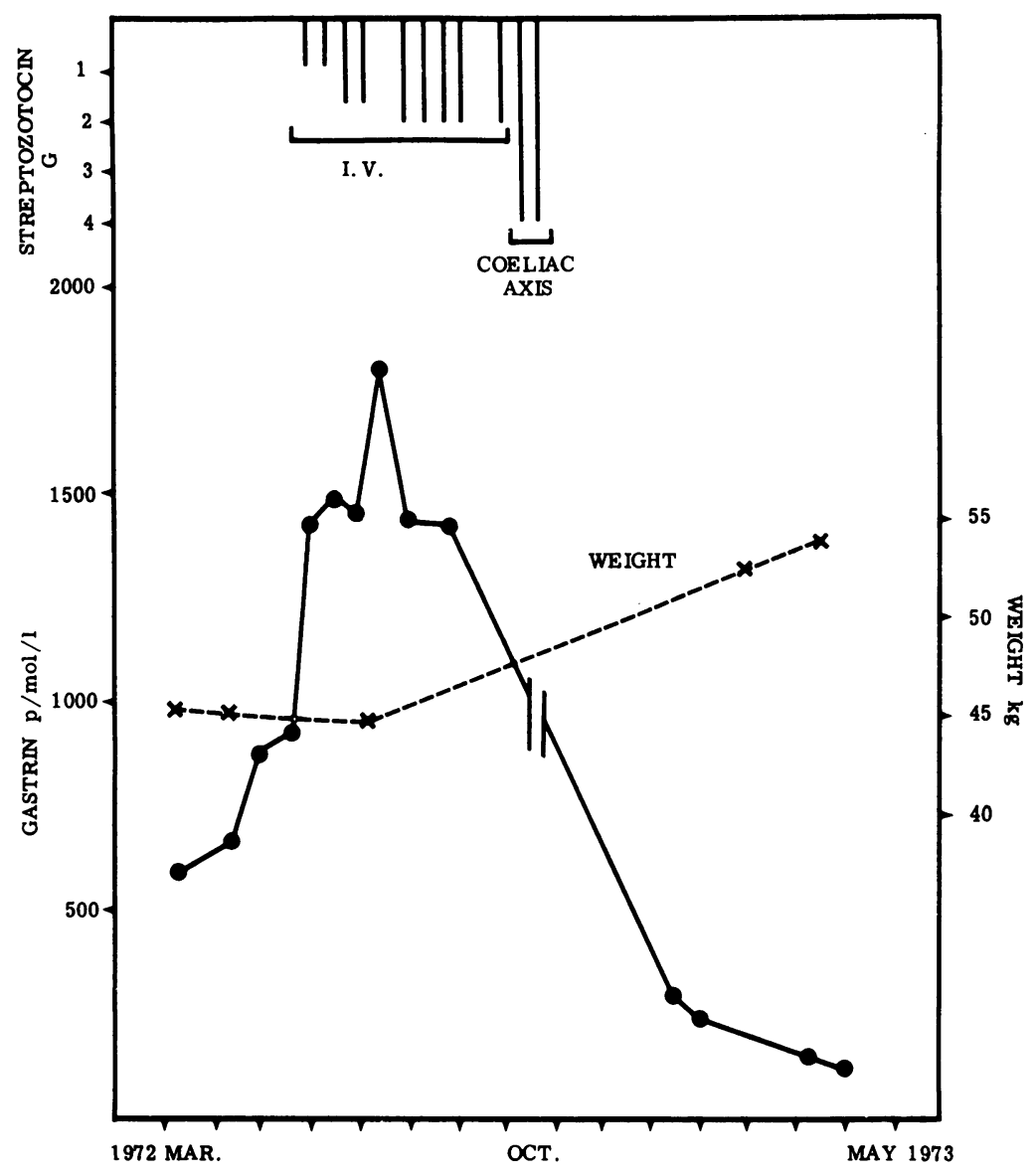

Figure Fasting gastrin values during treatment with streptozotocin. catheter passed percutaneously via the femoral artery into the coeliac axis and this dose was repeated 14 days later.

Before treatment, fasting plasma samples for gastrin, insulin, and glucagon assay were obtained. An oral glucose tolerance test was performed and the plasma samples obtained were assayed for glucose and insulin. These tests were repeated at the end of each treatment course. Before and after each dose of streptozotocin the urine was examined for glucose and protein and routine liver function tests were performed.

ASSAYS

Gastrin levels were measured using a sensitive and specific radioimmunoassay (Ardill, 1973). The assay uses antibody raised in rabbits to synthetic human gastrin I. The standard (human type synthetic 68/ 4399) was obtained from the Medical Research
Council. ${ }^{125}$ I labelled synthetic human gastrin with a specific activity of $700-900 \mathrm{uCi} / \mathrm{ug}$ was prepared using a modification of the chloramine $T$ method of Hunter and Greenwood (1962). The separation procedure used dextran coated charcoal. The sensitivity of the assay is $2-5 \mathrm{pmol} / \mathrm{l}$ and cross-reactivity with cholecystokinin/pancreozymin (Mutt) is $1 / 10000$ on a molar basis. The antibody reacts almost equally with molar equivalents of gastrin 17 and gastrin 34 and also recognizes 'big-big' gastrin.

Insulin was measured by a radioimmunoassay using antibody raised against pork insulin (McCarroll, 1971). The assay shows identical crossreaction between human insulin (MRC) and pork insulin. A charcoal separation technique was used. The sensitivity of the assay is $7 \mathrm{pmol} / \mathrm{l}$.

Glucagon was measured by an assay which used antibody raised against pancreatic glucagon and which reacts with the C-terminal portion of this 
molecule (Buchanan, 1973). Antibody reacting with the C-terminal has previously been considered 'pancreas specific'. However, some species of gut glucagon react with the C-terminal antibody (Flanagan et al., 1974) and $\alpha$ cells have been found in the duodenum (Unger and Orci, 1975). We therefore refer to the material measured by this assay as C-terminal glucagon-like-immunoreactivity (c-GLI). No cross-reaction has been noted with other gut or islet hormones. The sensitivity of the assay is 3-6 pmol/l. Hormone concentrations are expressed in pmol equivalents of the standard used.

\section{Results}

The fasting plasma gastrin before streptozotocin treatment was $600 \mathrm{pmol} / \mathrm{l}$ (Figure). The upper limit of normal in our assay is $95 \mathrm{pmol} / \mathrm{l}$. Fasting insulin was $0.05 \mathrm{nmol} / \mathrm{l}$ and cGLI was $70 \mathrm{pmol} / \mathrm{l}$. Both these values are within the normal range for the assays concerned. Intravenous streptozotocin therapy was without effect. Indeed fasting plasma gastrin rose from $600 \mathrm{pmol} / 1$ to $1430 \mathrm{pmol} / \mathrm{l}$ over a period of four months. However, when seen three months after intra-arterial streptozotocin the patient had noticed a marked change in well-being. She had gained $10 \mathrm{~kg}$ in weight and there was a marked reduction in hepatic size. The liver was only $3 \mathrm{~cm}$ below the costal margin and, while filling defects were still recognizable on liver scan, they were reduced in size. Fasting plasma gastrin levels on two occasions in January were $270 \mathrm{pmol} / \mathrm{l}$ and 240 $\mathrm{pmol} / \mathrm{l}$. When she was seen three months later, there was a further weight gain of $5 \mathrm{~kg}$ and fasting plasma gastrin levels were $140 \mathrm{pmol} / \mathrm{l}$ and $125 \mathrm{pmol} / \mathrm{l}$ on separate occasions.

Blood sugar values from glucose tolerance tests performed before treatment and after streptozotocin therapy are shown in Table 1. The corresponding insulin levels are shown in Table 2. The blood sugar values show the early peak seen in patients after gastrectomy. No change in glucose tolerance was noted over the treatment and follow-up period. Insulin values in both tests were comparable.

After intra-arterial streptozotocin, there was a transient rise in SGOT from 0.99 umol $\mathrm{S}^{-1} / 1$ to $2.01 \mathrm{umol} \mathrm{S}^{-1} / 1$ and in SGPT from $0.35 \mathrm{umol} \mathrm{S}^{-1} / 1$ to $1.02 \mathrm{umol} \mathrm{S}^{-1 / 1}$. At no time was either protein or glucose detected in the urine.

\section{Discussion}

Streptozotocin, an antibiotic derived from Streptomyces achromogenes, is selectively taken up by pancreatic islets where it is an inhibitor of pyridine nucleotide synthesis (Anderson et al., 1974). It has

\begin{tabular}{llrllllll}
\hline & \multicolumn{8}{c}{ Glucose levels (mmoll) at stated intervals (min) } \\
\cline { 2 - 9 } & 0 & 15 & 30 & 60 & 90 & 120 & 150 & 180 \\
\hline Before & 5 & 9 & 14 & 10 & 7 & 5 & 4 & 4 \\
After & 6 & 12 & 16 & 12 & 7 & 6 & 5 & 5 \\
\hline
\end{tabular}

Table 1 Blood glucose during oral glucose tolerance test before and after treatment with streptozotocin

\begin{tabular}{llllllllll}
\hline & \multicolumn{6}{l}{ Insulin levels $n$ moll l at stated time intervals $($ min) } \\
\cline { 2 - 9 } & 0 & 15 & 30 & 60 & 90 & 120 & 150 & 180 \\
\hline Before & 0.05 & 0.96 & 1.8 & 0.34 & 0.1 & 0.06 & 0.05 & 0.04 \\
After & C.05 & 1.1 & 1.4 & 0.47 & 0.21 & 0.07 & 0.04 & 0.4 \\
\hline
\end{tabular}

Table 2 Plasma insulin levels during an oral glucose tolerance test before and after treatment with streptozotocin

been found to be effective treatment in approximately $50 \%$ of patients with malignant insulinoma (Broder and Carter, 1973). Murray-Lyon et al., (1968) used streptozotocin successfully to treat a patient with a pancreatic islet cell tumour producing insulin, gastrin, and ACTH. However, in two reports where streptozotocin was used to treat islet cell tumours which produced gastrin alone, it was without effect (Broder and Carter, 1973; Passaro and Gordon, 1974).

Our patient had a history of recurrent severe peptic ulceration characteristic of the Zollinger Ellison syndrome. At laparotomy a pancreatic islet cell tumour was found and liver metastases were already present. Fasting gastrin levels were in the range expected in the Zollinger Ellison syndrome. She was at no time hypoglycaemic and measurements of basal plasma insulin levels were within normal limits. Plasma cGLI levels were within the normal range. Measurements of ACTH or plasma cortisol were not performed. Nevertheless, the clinical presentation was not suggestive of ectopic ACTH production nor were the electrolyte abnormalities characteristic of this condition present (Friedman et al., 1966). Plasma calcium was consistently within the normal range. We have no evidence that the tumour produced a hormone other than gastrin.

Two courses of intravenous streptozotocin were without effect. However, three months after two doses of streptozotocin of $4 \mathrm{~g}$ each had been given into the coeliac axis, there was a marked improvement in well-being, a reduction in hepatic size and a marked reduction in plasma gastrin level. In samples taken eight months after streptozotocin treatment the plasma gastrin levels were almost within the normal range. The median time to maximal bio- 
chemical response in successfully treated patients with insulinoma is $\mathbf{3 5}$ days and in some the maximal response is not seen until one year after therapy (Broder and Carter, 1973). The fact that the maximal clinical response in our patient was not seen until eight months after treatment is therefore not unusual.

In the reported cases of the use of streptozotocin in the Zollinger Ellison syndrome, the drug was given intravenously and as in our case was without effect (Broder and Carter, 1973; Passaro and Gordon, 1974). It is tempting to suggest that the eventual success of therapy in our patient was determined by the route of administration of the drug. The pattern of spread of pancreatic islet cell tumours makes them particularly suited to intra-arterial chemotherapy via the coeliac axis. Passaro and Gordon (1974) have commented that, despite the considerable tumour mass and duration of disease in patients they studied, there was no progression of metastases to extra-abdominal sites. It is possible that, in addition, intra-arterial infusion may reduce the incidence of side effects. Kahn et al. (1975) showed that infusion of streptozotocin into the coeliac axis resulted in a reduced urinary excretion of the drug as compared with excretion when the drug was given intravenously, thus reducing the possibility of nephrotoxicity. In our patient, glycosuria and proteinuria did not occur. The significance of the transient rise in SGOT and SGPT seen after the intra-arterial streptozotocin is difficult to interpret in a liver containing many metastatic deposits. Broder and Carter (1973) found evidence of transient hepatic toxicity in $67 \%$ of cases treated with streptozotocin. It has been suggested that streptozotocin is selectively toxic to the pancreatic B cell (Junod et al., 1967). It might, therefore, be expected that treatment with streptozotocin would result in the development of glucose intolerance. A mild to moderate abnormality of glucose tolerance has been seen in some patients treated with streptozotocin (Sadoff, 1969). In our patient, glucose tolerance tests performed before and after treatment were similar and the insulin levels seen during these tests were comparable.

Three years after treatment the patient remains well. However there has again been some increase in hepatic size and basal plasma gastrin levels are now greater than $600 \mathrm{pmol} / \mathrm{l}$. On the basis of our experience with this patient, we suggest that the infusion of streptozotocin into the coeliac axis may be of value in the management of the metastic complications of malignant gastrinoma.

We wish to thank Dr M. Young and Dr P. Daly for assistance in the management of this patient and are grateful to Dr K. D. Buchanan for his helpful advice with the assay techniques.

\section{References}

Anderson, T., Schein, P. S., McMenamin, M. G., and Cooney, D. A. (1974). Streptozotocin diabetes: correlation with extent of depression of pancreatic islet nicotinamide adenine dinucleotide. Journal of Clinical Investigation, 54, 672-677.

Ardill, Joy (1973). The Measurement of Gastrin by Radioimmunoassay. Thesis: Queen's University, Belfast.

Broder, L. E., and Carter, S. K. (1973). Pancreatic islet cell carcinoma. Annals of Internal Medicine, 79, 108-118.

Buchanan, K. D. (1973). Studies on the Pancreatic and Enteric Hormones. PhD. Thesis, Queen's University, Belfast.

Ellison, E. H., and Wilson, S. D. (1967). Ulcerogenic tumour of the pancreas. Progress in Clinical Cancer, 3, 225-244.

Flanagan, R. W. J., Buchanan, K. D., and Murphy, R. F. (1974). Specificity of antibodies in radioimmunoassay of glucagon. Diabetologia, 10, 365.

Friedman, M., Marshall-Jones, P., and Ross, E. J. (1966). Cushing's syndrome: adrenocortical hyperactivity secondary to neoplasia arising outside the pituitary-adrenal system. Quarterly Journal of Medicine, 35, 193-214.

Hunter, W. M., and Greenwood, F. C. (1962). Preparation of Iodine $^{131}$ labelled human growth hormone of high specific activity. Nature, 194, 495-496.

Isenberg, J. I., Walsh, J. H., and Grossman, M. I. (1973) Zollinger-Ellison syndrome. Gastroenterology, 65, 140-165.

Junod, A., Lambert, A. E., Pictet, R., Orci, L., Gonet, A. E. and Renold, A. E. (1967). Studies of the diabetogenic action of streptozotocin. Proceedings of the Society for Experimental Biology and Medicine, 126, 201-205.

Kahn, C. R., Levy, A. G., Gardner, J. D.. Miller, J. V., Gorden, P., and Schein, P. S. (1975). Pancreatic cholera: beneficial effects of treatment with streptozotocin. New England Journal of Medicine, 292, 941-945.

McCarroll, M. A. (1971). Insulin clearance by the isolated perfused rat liver. Thesis: Queen's University, Belfast.

Murray-Lyon, I. M., Eddleston, A. L. W. F., Williams, R., Brown, M., Hogbin, B. M., Bennett, A., Edwards, J. C., and Taylor, K. W. (1968). Treatment of a multiple hormone producing malignant islet cell tumour with streptozotocin. Lancet, 2, 895-898.

Passaro, E. Jr, and Gordon, H. E. (1974). Malignant gastriroma following total gastrectomy. Archives of Surgery, 108, 444-447.

Sadoff, L. (1969). Effects of streptozotocin in a patient with islet cell carcinoma. Diabetes, 18, 675-678.

Unger, R. H., and Orci, L. (1975). The essential role of glucagon in the pathogenesis of diabetes mellitus. Lancet, 1 , 14-16.

Walsh, J. H., and Grossman, M. I. (1975). Gastrin. New England Journal of Medicine, 292, 1377-1384. 